\title{
Prices of Agricultural Products and Poverty: How Strongly are the Two Linked?
}

\author{
Muhammad Arsyad \\ Department of Agricultural Socio-economics, Faculty of Agriculture, Universitas Hasanuddin, \\ Makassar, Indonesia, 90245, Indonesia. \\ E-mail:arsyad@unhas.ac.id
}

How to Cite: Arsyad, M. (2019). Prices of agricultural products and poverty: how strongly are the two linked? Int. J. Agr. Syst. 7(2): 148-153

\begin{abstract}
Prices of agricultural products and poverty relationship are the two types of standing issue to solve. This paper tries to argue that price of agricultural products (hereafter, agricultural price) and poverty are strongly related. We employed Correlation (intermediate step) and Path (final step) in the analysis procedure. The results show that, first, the association degree between agricultural input (note as well, that price is crucial factor to get input) with poverty approaching $70 \%$, indicating that agricultural input is good-fit in explaining poverty. Second, the higher the frequency of getting agricultural extension, and price information for various inputs (and output) in agriculture, the higher the crop productions (agricultural sector, in broad sense) will be gained. This indicates these two variables (inputs-outputs prices) can also be expected to be important instruments in increasing smallholders' income and in turn help them living above poverty line. Farmers household income is strongly affected by prevailing market price. Agricultural price is functioning as intermediate part of income calculation. It is clear that price of agricultural products has a strong linkage with rural poverty alleviation in the country.
\end{abstract}

Copyright $\odot 2019$ IJAS. All rights reserved.

\section{Keywords:}

Agricultural price; agricultural input-output; poverty

\section{Introduction}

Prices of agricultural products and poverty relationship are the two types of standing issue in developing countries. Teal (2011) emphasized that, poverty become central concerns of development economics. Some studies experienced this issue. Alivarez et al. (2018) found that commodity price can have a possibility to affect poverty alleviation. Increase in commodity prices has a positive effect on the economy (Estrades and Terra, 2012) and entrepreneurship [of course with price stability] as a solution to poverty (Morriis et al., 2020). Some crucial issue needs to re-consider when dealing with farmers welfare. First; the weak competitiveness of price. This was triggered by the existence of market monopoly practices by middlemen, although under certain conditions Arsyad, et al. (2018) showed that middlemen could contribute positively in terms of capital access and marketing for small-farmers in rural areas. 
Second; the absence of a processing industry supported by appropriate technology controlled by local farmers, and third; weak of institutional role in protecting farmers especially in terms of marketing (Callejo and Cossio, 2009) and post-harvest processing. Second, this is relevant to Lakitan's et al. (2019) findings, that the weak role of institutions is a causal factor of farmers not to be motivated to increase food production in wetlands. The same thing was revealed by Aini and Nadida (2014) that in order to improve infrastructure performance, it must be overcome by increasing the activities of institutional and farmer organizations.

Therefore, the institution is very important to be strengthened, given its huge contribution in accelerating the development of socio-economic farmers, accessibility of agricultural information; capital, infrastructure, marketing, and innovation in the agribusiness system (Nuddin et al., 2019). This is in line with the findings of Osorio and Rivas (2017) that the weakness of institutional programs has resulted in social forces that have not been able to produce solutions to social problems in the region. Therefore, institutional strengthening is an urgent need in developing socio-economic conditions of farmers.

It is widely known that some problems appear in smallholders in Indonesia. It has impact on low productivity and decrease amount of production due to trees aging and pests disease in plantation (Hidayanto et al., 2009). It also will affects socio-economic situation of smallholders (Hariyadi et al., 2009), agricultural land conversion (Kumala, 2016), increasing awareness, concern and product quality (Zhen and Routray, 2003) become crucial issue in the country (just like "peasant problem") (Neilson, 2008) and should be the main priority agenda (Jumiyati et al., 2018) in agriculture sector. Indonesian government has an effort to increase productivity from upstream to downstream have taken economic, social and environmental aspects into account by implementing various government policies (Bernstein, 2018) to increase income, poverty alleviation in other words. This paper tries to argue that price of agricultural products (agricultural price) and poverty are strongly related.

\section{Method}

Two subsequent steps of analysis were undertaken. First, testing association degree among variables in the dimension using Correlation (Person correlation, $r_{x y}$ ), in terms of the covariance (Pett et al., 2003; Knoke et al., 2002):

$$
r_{x y}=\frac{\operatorname{cov}(x, y)}{\sqrt{\operatorname{var}(x) \operatorname{var}(y)}}=\frac{s_{x y}}{\sqrt{s_{x}^{2} s_{y}^{2}}}=\frac{s_{x y}}{s_{x} s_{y}}
$$

where :

$s_{x y}=$ sample covariance for items $\mathrm{X}$ and $\mathrm{Y}, \operatorname{cov}(\mathrm{X}, \mathrm{Y})$

$s_{x}^{2}=$ sample variance for item $\mathrm{X}, \operatorname{var}(\mathrm{X})$

$s_{y}^{2}=$ sample variance for item $\mathrm{Y}, \operatorname{var}(\mathrm{Y})$; and

$s_{x}=\sqrt{s_{x}^{2}}=$ the standard deviations for item $\mathrm{X}$ 
Second, we employed our previous model of Path Analysis to explain different issue. The general model of PA is developed below;

$Y_{t}=\beta_{1} X_{1 t}+\beta_{2} X_{2 t}+\ldots+\beta_{k} X_{k t}+E_{t}$, for $Y_{t}, X_{i t}$ is standardized and $t=1,2, \ldots, n$ yields the following equations:

$$
\mathrm{Y}_{\mathrm{t}}=\left(\sum_{q=1}^{K} \beta_{q} X_{q t}\right)+\mathrm{E}_{\mathrm{t}} \text { in which the direct influence of exogenous variables on }
$$

each of its respective endogenous can be estimated by path equation.

\section{Results and Discussion}

\subsection{Input Association Degree in Agriculture}

This session will focus on agricultural input factors. It was successfully constructed variables in the analysis of this aspect. In fact, this factor has the highest number of variables and it produces a larger number of variable combinations within the factor. Initially (before constructing Factor Matrix), there were eighty-nine variable combinations within this specific dimension as a whole. It was found that almost $42 \%$ variable combinations have significant associations in the analysis. This figure leads us to say that those variable combinations within the agricultural input cluster are good enough to explain poverty. If we carefully see the association degree within the specific dimension of the analysis, the agricultural asset/input is the second strongest factor (almost $42 \%$ ) after human resource. An interesting point is, the association degree between agricultural input with poverty approaching $70 \%$. This percentage placed the agricultural input as the strongest dimension after agricultural business $(60.00 \%)$ or slightly less than the highest one.

Besides, the average association degree between this specific factor (agricultural input) and the other five dimensions are also stronger (almost 16.00\%). It indicates that the agricultural input factor could be strongly considered as an important aspect when dealing with rural poverty alleviation. This is not without reason. Agricultural input has a strong linkage with the other five dimensions in the analysis. Another crucial point is that of those five dimensions that have associations with the agricultural input factor, surprisingly, the agricultural business still has stronger association (almost $17.00 \%)$. This again conveys a crucial message that outside of the agricultural input, the agricultural business activity still plays an important role in describing poverty situation. This might be one of the probable reasons why agricultural sector is strongly associated with rural poverty, meaning that agricultural sector should strongly be considered when dealing with poverty reduction policy both in central and local government levels.

\subsection{Agricultural Input, Output Price and Poverty Reduction}

In our previous model, we estimated some variables dealing with agricultural input by proxied "household income" as poverty measurement unit. There are seven independent variables \{Family Structure with Education $\left(\mathrm{X}_{12 \mathrm{~m}}\right)$, Cultivated Land Area with Farm Equipment $\left(X_{21 \mathrm{~m}}\right)$, Farm Equipment $\left(X_{22 \mathrm{~m}}\right)$, Coffee and Paddy Field Area with Farm Equipment $\left(X_{25 \mathrm{~m}}\right)$, Paddy Upland Area $\left(X_{27 \mathrm{~m}}\right)$, Social Service Utilization $\left(X_{33 \mathrm{~m}}\right)$ and Agriculture \& Non-Agriculture Extension $\left.\left(X_{42 \mathrm{~m}}\right)\right\}$ that send their direct effects on "Household Income $\left(X_{7 m}\right)$ ". Five out of seven variables have direct positive effects i.e. the variable Family Structure with Education $\left(\mathrm{X}_{12 \mathrm{~m}}\right)$, Cultivated Land Area 
with Farm Equipment $\left(X_{21 m}\right)$, Farm Equipment $\left(X_{22 m}\right)$, Social Service Utilization $\left(X_{33 m}\right)$ and Agriculture \& Non-Agriculture Extension $\left(X_{42 \mathrm{~m}}\right)$. However, we will explain agricultural input only in this paper. We will classify these variables below. Of these five variables that have direct positive effects, the variable Social Service Utilization $\left(X_{33 \mathrm{~m}}\right)$ has a stronger effect $(\beta=.444)$ followed by the variable Cultivated Land Area with Farm Equipment $\left(X_{21}, \beta=.373\right)$, Agriculture \& Non-Agriculture Extension $\left(X_{42 \mathrm{~m}}\right.$, $\beta=.276)$, Farm Equipment $\left(X_{22 m}, \beta=.245\right)$ and Family Structure with Education $\left(X_{12 m}\right.$, $\beta=.242$ ). These latter four variables are categorized into the moderate effects in our interval of $\beta$ weights.

There are two important agricultural input considered in the analysis. They have direct positive effects on "Household Income $\left(X_{7 \mathrm{~m}}\right)$ " i.e. "Cultivated Land Area with Farm Equipment $\left(X_{21 \mathrm{~m}}, \beta=.373\right)$ " and "Agriculture \& Non-Agriculture Extension $\left(X_{42 \mathrm{~m}}, \beta=\right.$ .276)". Based on the model constructed, there are two crucial interpretations deals with these results, statistically. First, it is probable to say that the larger cultivated land (with farm equipment) is, the higher the production will be and the more household income will be generated, resulting in poverty alleviation of small-farmers. However, it is important to note that, household income is strongly affected by prevailing market price. Agricultural (output) price in the analysis is functioning as intermediate part of income calculation. The higher the price, the more household income will be. This is telling us that, price will become very important determinant in this interpretation. In other words, price level of agricultural products will affect household income seriously. This finding reminds that price of agricultural output is strongly linked with poverty of rural smallholders. It is understandable that price of agricultural outputs is not a single factor to alleviate poverty. Some important aspects (Nuddin et al., 2019) need to consider; the coordination effectiveness among institutions in agriculture, human resource development, crop management and intervention, agro-industry system, provision of production inputs, marketing development in broad sense, and improvement of institutional functions.

Second, the variable Agriculture and Non-Agriculture Extension $\left(\mathrm{X}_{42 \mathrm{~m}}\right)$ also have significant direct positive effect on "Household Income $\left(X_{7 \mathrm{~m}}\right)$ " which can be interpreted, that the higher frequency of getting agricultural extension information, price information for input-output in agriculture, the higher the crop productions (agricultural sector in broad sense). In addition, these variable combinations are also creating a positive impact on 'non-agricultural' income of small-farmers in rural area. This conveys important message that, these variables can also be crucial determinants in increasing smallholders' total income (both agriculture and non-agriculture income). In the research site, smallholders who have more farm equipment (plow, sprayer, etc.) tend to have better positions in agricultural production (smallholders are not able to produce agricultural products without such farm equipment in other words). In addition, they can also receive the rent from their farm equipment's (for instance, hand tractor was rented by other smallholders in ploughing their land), so that their total income (equipment owners) will increase. This leads us to argue that, expanding cultivated land with improving farm equipment (as well as stepping up agricultural and non-agricultural extension services) would become important intervention ways to help the smallholders move out of poverty in the region. 


\section{Conclusion}

It can be concluded; the association degree between agricultural input (note as well, that price is crucial factor to get input) with poverty approaching $70 \%$, indicating that agricultural input is good-fit in explaining poverty. The higher the frequency of getting agricultural extension, and price information for various inputs (and output) in agriculture, the higher the crop productions (agricultural sector, in broad sense) will be gained. This indicates that these two variables (inputs-outputs prices) can also be expected to be important instruments in increasing smallholders' income and in turn help them living above poverty line. Household income is strongly affected by prevailing market price. Agricultural price is functioning as intermediate part of income calculation. It is clear that price of agricultural products has a strong linkage with rural poverty alleviation in the country.

\section{Acknowledgements}

Authors like to thank Directorate General of Higher Education, Ministry of Research, Technology and Higher Education, National Research and Innovation Board, Republic of Indonesia for research funding (Applied Research Scheme, 2019-2021) through Research Institute and Community Services (LP2M), Universitas Hasanuddin. Special thanks to provincial local government, university partner and all farmers for good cooperation during the field research and Focus Group Discussion on early drafts of this paper.

\section{References}

Aini, Y. N., and Nadida, Z., (2014). Analisis Kelembagaan Petani dalam Mendukung Keberfungsian Infrastruktur Irigasi (Studi Kasus: Daerah Irigasi Batang Anai, Sumatera Barat). Jurnal Sosek Pekerjaan Umum, 6(3): 140-221.

Alivarez, R., A.G. Marin and S. Ilabaca, (2018). Commodity price shocks and poverty reduction in Chile. Resources Policy, in press.

Arsyad, M., H, Heliawaty., Y, Kawamura., and S, Yusuf, (2018). Agricultural Development-Marketing Nexus: Is Tengkulak truly Enemy of Smallholders in Indonesian Rural Area? International Journal of Agriculture System (IJAS), 6(1): 6067.

Bernstein H, (2018). The 'peasant problem' in the Russian revolution (s), 1905 - 1929 J. Peasant Stud. ISSN 45:1127-50.

Callejo del, I and V. Cossio, (2009). Institutional Aspects of Sustainability for Irrgated Agriculture in Arid and Semi-Arid Regions. Chilean Journal of Agricultural Research. 96(Suppl.1): 41-53.

Estrades, C. and M.I. Terra (2012). Commodity prices, trade, and poverty in Uruguay. Food Policy, 37(1):58-66.

Hariyadi, U.S. and IW W (2009). Identification of problems and solutions for developing cocoa plantation communities in North Luwu Regency, South Sulawesi Province. Proc. Semin. IPB Res. Results.

Hidayanto, Y., Amien (2009). Analysis of the sustainability of cocoa plantation communities in the border region of Sebatik Island, Nunukan Regency, East Kalimantan Province. Agro Econ. J. 27: 213-29

Jumiyati S, Arsyad M, Pulubuhu D A T and Hadid A., (2018). Cocoa based agroforestry: An economic perspective in resource scarcity conflict era IOP Conference Series: Earth and Environmental Science vol 157 (IOP Publishing) p 12009. 
Knoke, D., G.W. Bohrnstedt and A.P. Mee, 2002. Statistics for Social Data Analysis. Fourth Edition. Peacock Publishers, Illinois.

Kumala, (2016). Design a sustainable cocoa agro-industry supply chain model using smart systems (Bogor (ID): Institute Bogor Agriculture.).

Lakitan, B., Lindiana, L., Widuri, L. I., Kartika, K., Siaga, E., Meihana and M., Wijaya, A. (2019). Inclusive and Ecologically-Sound Food Crop Cultivation at Tropical Non-Tidal Wetlands in Indonesia. AGRIVITA Journal of Agricultural Science, 41(1), 23-31. http:/ / doi.org/ 10.17503/ agrivita.v40i0.1717.

Neilson, J (2008). National movement program to accelerate national cocoa revitalization (Gernas). [Internet]. [downloaded 2018 August 15].

Osorio, A. A. and A. Rivas. G, (2017). Contribution of Local Peasant Innovations to the re-cofiguration of Endegenous Rural Development. Journal Agronomia Colombiana. 35(3): 365-373.

Pett, M.A., N.R. Lackey and J.J. Sullivan, 2003. Making Sense of Factor Analysis: The Use of Factor Analysis for Instrument Development in Health Care Research. Sage Publications, London.

Teal, F., (2011). The price of labour and understanding the causes of poverty. Labour Economics, 18(S1):7-15.

Zhen L and Routray J K (2003). Operational indicators for measuring agricultural sustainability in developing countries Environ. Manage. 32 34-46. 